\title{
An Exploratory Research Regarding the Visibility of the Mission Statements on the Airline Company Websites
}

\author{
Serap Benligiray (Corresponding author) \\ Anadolu University, Faculty of Economics and Administrative Sciences, Department of \\ Business Administration, Eskisehir, Turkey \\ Tel: 90-222-335-0580 / 3377 E-mail: sbenligi@anadolu.edu.tr

\begin{abstract}
Gamze Ozsoy
Research Assistant, Anadolu University, Faculty of Aeronautics and Astronautics, Department of Aviation Management, Eskisehir, Turkey

Tel: 90-222-321-3550 / 6962 E-mail: gozsoy@anadolu.edu.tr

Cengiz Mesut Bukec

Anadolu University, Graduate School of Social Sciences, Department of Aviation Management, Eskisehir, Turkey
\end{abstract}

Tel: 90-222-324-3800 / 2054 E-mail: cengizmesutbukec@gmail.com

Received: Oct. 30, 2012 Accepted: November 19, 2012 Published: January 1, 2013

doi:10.5296/jmr.v5i1.2594

URL: http://dx.doi.org/10.5296/jmr.v5i1.2594

\begin{abstract}
The aim of this study is to display how efficient the airline companies use their websites to announce their mission statements to stakeholders. This qualitative research, for which content analysis is used, has a sample group of 252 companies. It has been determined that $70 \%$ of the companies announce their mission statements on their websites, $40 \%$ of them do it under the title "Our Mission", the companies usually give two language options (native and English), even if there are more, they are usually not available for mission statements, the most frequent location for the mission statement is the second, the least frequent is the homepage. This study concludes that the websites are not being used efficiently to reach their stakeholders.
\end{abstract}

Key words: Airline Mission Statements, Mission Communication, Airline Websites 


\section{Introduction}

Mission is a crucial and comprehensive statement that explains the purpose of existence of an organization, exhibits the distinguishing philosophy, values and main objective among similar organizations and defines the operations, products/services, market and responsibilities of the organization (Bart, 1996, 1999; Drucker, 1973; Klemm, Sanderson \& Luffman, 1991; Want, 1986).

Management literature consists of numerous views regarding the benefits to be derived from designation of a mission and sharing the mission with the stakeholders (e.g., Campbell, 1997; Ireland \& Hitt, 1992; Rigby, 1998). Besides, mission statements are seen as a significant marketing and public relations tool. Furthermore, mission statements have become an important part of stakeholder relations and reputation management of today's companies (Leuthesser \& Kohli, 1997). Taking all of these characteristics into consideration, a mission statement indeed is a public statement (Bartkus \& Glassman, 2008).

Companies may utilize various tools in order to convey their mission statements to their internal and external stakeholders. If compared with booklets, reports, printed media tools, television, commercials and speeches, the use of websites on Internet could said to be one of the most significant communication tools for sharing the mission with the stakeholders. Seeing that, companies obviously are well aware of the substantiality of it. However, it is necessary to use the mission effectively in order to obtain the positive results. To use the mission with utmost effectiveness, the mission statement and all of its elements should be placed in the website where it can be easily found and reached, while expressing the mission in an understandable language.

Based on the hypothesis that the websites of the businesses which are acting globally should have comparable qualities, as they are trying to reach the same global stakeholders (Pearce \& Roth, 1998), the objective of this research is to seek an answer to questions such as; if the airline companies publish their mission statements on their websites, whether the mission is published in an integrated or a sporadic fashion, which category the mission is included in, and which page the mission statement is published on. This report uses an exploratory research to show whether airline companies use their websites as an effective channel to convey their mission statements to their stakeholders and to provide suggestions to boost this intention.

\section{The Importance of the Mission Communication through the World Wide Web for Airline Companies}

The rapid development in communication technologies and particularly the Internet has provided new opportunities for the airline companies. The most prominent opportunity can said to be commented in online sales and distribution. Another influence of the Internet and other information technologies on airline industries is the rapid increase in self-service practices. These allow self-serving reservation, ticketing, and check-in services on a virtual platform, which eliminates the involvement of an intermediary. A brand new electronic market has emerged for airline companies by means of these new e-trade tools (General 
Accounting Office [GAO], 2003). Currently, the Internet provides great convenience regarding global access with less geographical constraints and local regulatory limits. Recently, the Internet has become one of the few media that can overcome cultural restraints (Bennett, 1997). Finally, the Internet ensures an alternative setting for intercultural marketing in a global market (Hamill, 1997).

Today, it is inevitable for the airline companies to use the Internet and have an official website (Benckendorff, 2006). Airline companies are encouraging their customers to use the cost effective online channels and websites instead of their traditional reservation and ticketing channels (Lubbe, 2007). Thus, customer relations are brought into prominence through the Internet and websites. Companies in the competilive business world should create long-term relations with their customers and establish sentiments such as trust, loyalty, and commitment that would reinforce the perception of enrichment and relations (Harker, 1999). The Internet and websites are undoubtedly proper means of mass communication in customer relations (Chaffey, Mayer, Johnston \& Ellis-Chadwick, 2003; Gilbert, Powell-Perry \& Widijoso, 1999; Peppers \& Rogers, 2001; Yelkur \& Dacosta, 2001). Official websites are important channels that enable the companies to reach their target audience (Robbins \& Stylianou, 2001-2002)

Global and multi-component airlines area is an information industry. Even though the primary output of the air transportation is flight service, the customers purchase the service information before the service itself. Today, as customers' expectations regarding the product and service increase, their demands regarding the information related to the service have increased (Kuyucak, 2007). These customer demands also include information about the company. Website visitors are more likely to be highly involved and active in terms of information acquisition (Chakraborty, Srivastava \& Warren, 2005).

In the airline industry, information is an integrative element, which unites different producers and servers from various geographical regions. These differing sides are organized as a network and the finished product is formed through information flow, communication and service flow (Kuyucak, 2007). Hence, Business-to-Business (B2B) relations are crucial to airline companies. In terms of $\mathrm{B} 2 \mathrm{~B}$, appearance of the information on an official website is even more important due to the financial risks and the complexity of the variations in the process regarding the typical B2B proceedings (Peppers \& Rogers, 2001).

Air transportation is a highly outward-oriented industry. Therefore, it is open to ecological, social, political and other environmental factors. Within this industry-environment interaction, transparency and adequate information distribution is crucial in order to satisfy all parties and prevent conflicts (Kuyucak, 2007).

One of the components forming an airline service delivery is image. The term "image", indicates the overall appearance of the airline company that is established in the minds of the customers and the public opinion about the company. Safety is the most important component of the image of an airline company (Doganis, 2005). Mission and vision are often the main elements that set the public image of a company. External stakeholders are able to get familiarized and evaluate the companies using these indications, and they can handle public 
relations more effectively (Benligiray, Geylan \& Duman, 2009).

Whenever the stakeholders (e.g., personnel, customers, shareholders, suppliers) reach the mission statement, they are entitled to consider all or some of the following statements: 1) This company is well-managed. Because, in accordance with the current management literature, the mission is an important management tool that aims to unite everyone around a common philosophy, value system, and objectives (Campbell, 1992; Greengarten-Jackson, Yau, Gitlow \& Scandura, 1996; Rigby, 1994). Furthermore, a mission statement with specified results eliminates the confusion, uncertainty, and conflicts regarding the objectives, roles, and tasks of the employees (Fisher, 1983). 2) This company is a focused organization. This reassures that the company has a consistent direction (Stolkey, 2004). One of the main reasons of the business failure is the inability of the senior management to define the purpose of the organization (Bart, 1997). A professionally prepared mission helps the organization focus on its primary area of activity and its raison d'etre (Bart \& Baetz, 1998). 3) This organization wishes to improve its competitive position (Rigby, 1994). Specification of the mission increases the companies' competitiveness (Campbell, 1989, 1993; Campbell \& Yeung, 1991). 4) This organization thinks strategically. Mission is seen as the starting point of almost all strategic initiatives (Bart, 1997). 5) This organization is a consistent entity focusing on its activities in the long-term. Mission statements are generally deemed important for long-term earnings and survival of the company (Pearce, 1982). 6) This company uses contemporary administration techniques. As in quality management, restructuring and self-governing groups, it is required to determine the mission at the beginning of the contemporary administration techniques (Bart, 1997). 7) This organization cares about its stakeholders and tries to unite them on a common ground (Klemm et al., 1991). Mission is expected to balance the interests and needs of internal and external competitive stakeholders (Bart, 1999). 8) This organization uses its resources efficiently. An organization with a determined mission is expected to reflect its priorities and the balance set in the mission while allocating resources. Consequently, the limited resources of the organization can efficiently be distributed (Bart, 2001). Even the possibility of making the stakeholders consider these ideas shows the importance of sharing mission statements with the stakeholders of the company.

\section{Visibility of the Mission Statements on the Web}

Today, airline companies use their official websites in order to conduct an extensive communication with visitors from various parts of the globe. Due to this extensive utilization, it is crucial for the web developers and administrators to create and maintain websites that satisfy the user needs. However, it has never been easy for airline companies to find the most favorable way of designing an official website that would be considered effective in a multicultural environment (Chakraborty et al., 2005). Upon the conducted research, it has been suggested that the effectiveness of the website is related to three elements. The first of these elements is "content", which addresses to all of the features offered by the website. Useful, correct, up to date and extensive content is the second element, which can also be referred as "content quality". The last element is the "design" of the website, which emphasizes the ease of navigation and usage of the website and its qualities of being consistent and interesting. The research done on the effectiveness of the websites are 
generally related to these three elements (e.g., Breitenbach \& Van Doren, 1998; Ho, 1997; Jeong, Oh \& Gregoire, 2003; Murphy, Forrest, Wotring \& Brymer, 1996; Perdue, 2001; Rachman \& Richins, 1997).

The website visitors demand to find the information they are interested in. The official website of an airline company is the introduction of the company as well as an entrance for the visitors that would allow them to find critical information (such as mission statements), which forms their perception regarding the identity of the company as a whole. If the visitors are not able to find helpful and relevant information on the website of a company, they most likely tend to adopt a lesser perception regarding the company and visit rival company websites which provide the required information and conduct their business with these companies (Chakraborty et al., 2005).

Website visitors should be able to locate the information they are seeking on the website easily. When the visitors find the information they seek, they decide to see the next page. In the meantime, they need to monitor the page they have already opened. A convenient design and navigational assistance (e.g., menus) helps the user to form a mental image regarding the organization of information on the website and the information the website offers (Van Berkel $\&$ de Jong, 1999). For the developers, high quality content development and achieving an optimal design regarding the ease of reach to relevant information, and for the users, delays on downloading content and the necessity to make multiple hits for a single query might be overwhelming (Palmer, 2002).

Conducted researches address publishing mission statements on the Internet as a common practice. Many organizations may utilize their websites as a tool to communicate the mission. However, there are still only a handful of guides that would lead the web administrators to effective presentations. Very few of the companies know how to use these websites to convey information regarding the missions and business strategies to their stakeholders (Bartkus, Glassman \& Mcafee, 2002).

It is crucial for the stakeholders of an airline company to be aware of the primary duty, business approach, values, and the responsibilities of the company to the stakeholders. Stakeholders are able to reach this information (if such information is available) through various channels. However, reaching it through websites is far more practical and economical. In this case, the website should contain such information in an easily reachable location, written in an easily understandable language. In this study, we will seek answers to our question because of the reasons stated above.

\section{Design of Study}

The sampling of this research consists of 252 airline companies, 237 of which are IATA (International Air Transport Association, whose members cover 93\% of the international commercial passenger and cargo transportation) members and 100 of which are listed in the Top 100 Airline Groups Ranked by Revenues 2009 list published by Airline Business. As some companies are present in the both groups, there are a total of 252 companies that are examined in the research. 152 companies are only IATA members $(60.3 \%), 15$ companies are 
in the Top 100 list but not members of IATA (6.0\%) and 85 companies are both IATA members and are on the Top 100 list.

The websites of the 252 companies in the sampling are examined using content analysis. The examination is done by two coders simultaneously and in coordination, and completed with cross-checking. The findings are reported with their frequencies and cross-tables. The names and website addresses of the companies in the sampling are added in the Appendix-A in alphabetical order.

The first element searched in the websites was the term "mission", in a link or as a title. If this search did not yield any results, mission statement (as a whole or along with its components) is searched through the search engine of the website. Since there are no built-in site-search systems in some websites and it is possible to overlook some components during the analysis, an additional Google search was executed. During this inquiry, the terms, "mission, vision, strategy, management philosophy, values and responsibilities" and the name of the company are used.

Finally, the researchers contacted the airline companies that do not have their mission statements on their websites. A query e-mail was sent to the webmaster of the company particularly to confirm the findings collected from these searches. This e-mail included a brief explanation regarding the research. In addition, the e-mail conveyed that no mission statements were found in the website and this finding would be reported accordingly in the research. A request to contact our research group if they thought the information is incomplete or inaccurate was sent to the webmasters. Two companies replied to these queries; one of which explained that the company was under complete restructuring, and the latter stated that the mission statement was still under discussion.

The rest of the research is done on the company websites that include a mission statement. During the next stage of the research, in which categories the mission statements were presented was examined (e.g., home page, about company, corporate info/governance, investor/customer relations). If these categories are nested in each other, the category just above the mission statements was assumed to be the containing category. When the mission statement could be found in a category readily listed in our research template, annual report of the company was not analyzed. Corporate info/governance was listed as a category providing information regarding the corporate characteristics of the company, and corporate/company culture was listed as a category that defines the mission statements within the organizational culture of the company and combines this with the philosophy of the organization. Code of Ethics/Conduct is also related to the organizational structure, but as this document is given as a separate statement and consists of the statutory rules to be adopted by the employees, therefore it is considered as a different category.

The questions asked in the next phase are as follows: Where is the mission statement placed within the website? In which page does a visitor will find the mission statement? The location of the mission statements is recorded according to the page number of the mission statements. A page number was not allocated for the Home Page. Each following "click" was considered as another page and the first "click" from the Home Page was considered as page 1 (e.g., 
Page $0=$ company home page/a link on the Page 0 was clicked (click 1 ) and the resulting page is Page 1/ a link on the Page 1 was clicked (click 2) and the resulting page is Page 2, etc.).

Another objective of this study is to detect the number of languages used to convey the mission statement. This is the more laborious part of the study, as there are many languages being actively used in the world (e.g. Greek, Indian, Persian, German, English, Italian, French, Spanish, Russian, Bulgarian, Serbian, Arabic, Hebrew, Chinese, Tibetan, Finnish, Hungarian, Turkish, Mongol, Manchu, Tungusic, Korean, Japanese, Ethiopian, Afrikaan etc.)

While we are familiar with some of these languages, we have encountered some of them for the first time. Each language option of all websites were visited individually, and then the language that is determined by Google Translate is assumed as true. In some websites, the language options are presented both with their English names and their native names. However, most sites presented the language options in their native names. When Google Translate fails to find the language or the result is doubtful, further research was made about the used language.

The research regarding in which languages the companies present their mission statements was started by the page which has the term "mission" in its English correspondent. Then other language options were chosen in the said page, the pages are translated with Google Translate, and checked if they contain the word, mission. When Google Translate failed to translate a language, the location of the mission statement in the English page is found and checked whether it's included in all language options.

\section{Findings}

In this research, the websites of a total of 252 airline companies are analyzed. The sampling consists of 16 companies from both the United States and China (People's Republic of) (12.6\%), 11 companies from Germany (4.4\%), 9 companies from both Russian Federation and the United Kingdom, 7 companies from Turkey, 6 companies from South Africa, 5 companies from France, India and Iran (Islamic Republic of), 4 companies from Israel and Italy, 3 companies from Argentina, Australia, Brazil, Ireland, Sweden, Japan, Korea (Democratic People's Republic of), Mexico and Singapore, 2 companies from Austria, Bahrain, Belgium, Ecuador, Finland, French Polynesia, Croatia, Hong Kong, Colombia, Kuwait, Luxembourg, Malaysia, Norway, Peru, Romania, Chile, Thailand, Tunisia, Ukraine, Jordan and Greece and 1 company from Angola, Albania, Azerbaijan, United Arab Emirates (UAE), Bangladesh, Belarus, Bosnia and Herzegovina, Brunei Darussalam, Bulgaria, Cape Verde, Algeria, China, Chinese Taipei (Taiwan), Czech Republic, Denmark, El Salvador, Indonesia, Armenia, Estonia, Ethiopia, Fiji, Philippines, Guam, Georgia, Netherlands, Switzerland, Iceland, Montenegro, Qatar, Kazakhstan, Kenya, Cyprus, Costa Rica, Cuba, Latvia, Libya, Libyan Arab Jamahiriya, Lebanon, Hungary, Madagascar, Malawi, Malta, Mauritius, Egypt, Mongolia, Moldova (Republic of), Morocco, Mozambique, Namibia, Nigeria, Pakistan, Panama, Papua New Guinea, Paraguay, Trinidad and Tobago, Poland, Réunion, Seychelles, Serbia, Slovenia, Sri Lanka, Sudan, Suriname, Syrian Arab Republic, Saudi Arabia, Tanzania (United Republic of), Oman, Uruguay, Vanuatu, Vietnam, Yemen, New Caledonia, New Zealand and Zimbabwe. 87 of these companies are from Europe 
(34.4\%), 80 of them are from Asia (31.7\%), 28 of them are from Africa (11.1\%), 25 of them are from North America (8.3\%), 21 of them are from South America (8.3\%) and 11 of them are from Australia (4.4\%).

Out of 252 companies, $174(69.1 \%)$ included their mission statements explicitly or implicitly to their websites, while $78(31.0 \%)$ of them did not have a statement regarding their mission. $150(86.2 \%)$ of the 177 companies presented their mission statements at their own websites, while 24 of them $(13.8 \%)$ presented the mission statement at the websites of the holdings they are affiliated with. While the mission statements of 101 (58.0\%) companies were presented as a whole, mission statements of $73(42.0 \%)$ companies were spread to the different pages of their websites. Among the companies which presented their mission statements non-fragmented in their websites, the mission statements were placed under the title "Our Mission" by 86 (49.4\%) companies, while 15 (8.6\%) companies placed it under the "Mission" link.

Table 1 displays the relationship between the continent in which the company resides and the tendency of the company to publish their mission statement at their websites. $24(30.8 \%)$ of the European airline companies, $26(33.3 \%)$ of the Asian companies, 11 (31.0\%) of the African companies, 9 of the North American companies, 1 of the South American companies and 7 of the Australian companies didn't publish the mission statement at their websites. 63 (36.2\%) of the companies which publish their mission statement at their websites are European, 54 (31.0\%) are Asian, 20 (11.5\%) are South American, 17 (9.8\%) are African, 16 (92.\%) are North American and 4 (2.3\%) are Australian (see Table 1).

$72(30.4 \%)$ of the 237 companies which are members of IATA and $21(21.0 \%)$ of the (Airline Business' list of) Top 100 companies have no information regarding their mission statements on their websites. 95 (54.6\%) companies out of 174 are only members of IATA, $9(5.2 \%)$ are only on the Top 100 list, and $70(40.2 \%)$ are both IATA members and are on the Top 100 list (see Table 1).

$173(99.4 \%)$ of the companies which publish their mission statements on their websites had an English website. The one company that did not was Air Madagascar. 77 (44.3\%) companies had German, 75 (43.1\%) had French, 73 (42.0\%) had Spanish, 56 (32.2\%) had Italian, 50 (28.7\%) had Russian, 47 (27.0\%) had Chinese, 46 (26.4\%) had Portuguese, 36 $(20.7 \%)$ had Japanese and $30(17.2 \%)$ had Korean language options on their websites. 77 (44.3\%) companies had one or more of the following language options: Dutch, Turkish, Polish, Swedish, Danish, Norwegian, Arabic, Hungarian, Greek, Czech, Thai, Finnish, Romanian, Slovak, Bulgarian, Estonian, Hebrew, Slovenian, Catalan, Vietnamese, Croatian, Ukrainian, Serbian, Latvian, Persian, Lithuanian, Indonesian, Kazakh, Malay, Albanian, Macedonian, Armenian, Swahili and Afrikaans.

$18(10.3 \%)$ of the airline companies had no language options. While the website of the Air Madagascar was French, the websites of the other companies were in English. 58 (33.3\%) companies had two language options, $18(10.3 \%)$ had three, $12(6.9 \%)$ had four, $10(5.7 \%)$ had five, $12(6.9 \%)$ had six, $7(4.0 \%)$ had seven, $5(2.9 \%)$ had eight, 7 (4.0\%) had nine and $27(15.5 \%)$ had ten or more language options available on their websites. It has been noticed 
that the airline companies in cargo business had more language options on their websites. 5 of the companies that had more than 10 language options on their websites were airline cargo companies. DHL Air and DHL International had 33, TNT Airways had 30, UPS (United Parcel Service) Airlines- had 22 and FedEx (Federal Express) had 20 language options on their websites.

49 airline companies published their mission statements in one language, 71 did in two, 14 did in three, 8 did in four, 7 did in five, 6 did in six, 4 did in seven, 3 did in eight, 3 did in nine and 9 did in ten or more languages. TNT Airways had 29 and UPS Airlines had 22 language options for their mission statements. Table 2 demonstrates the relationship between the language options for the websites and the language options for the mission statements.

Table 1. The relationship between the continental location of the airline companies and the presence of the mission statements on their websites

\begin{tabular}{|c|c|c|c|c|c|}
\hline & \multicolumn{4}{|c|}{ PRESENCE OF THE MISSION } & \multirow{4}{*}{ Total } \\
\hline & \multicolumn{3}{|c|}{ Has a mission } & \multirow{3}{*}{$\begin{array}{c}\text { Does not } \\
\text { have a } \\
\text { mission }\end{array}$} & \\
\hline & \multicolumn{3}{|c|}{ How the mission is published in the website } & & \\
\hline & $\begin{array}{c}\text { Under the title } \\
\text { "Our } \\
\text { mission" }\end{array}$ & $\begin{array}{l}\text { Under the } \\
\text { link } \\
\text { "Mission", } \\
\text { below } \\
\text { different titles }\end{array}$ & $\begin{array}{l}\text { Not } \\
\text { specified as } \\
\text { the mission } \\
\text { but has the } \\
\text { content }\end{array}$ & & \\
\hline \multicolumn{6}{|c|}{ The continental locations of the companies } \\
\hline Europe & 23 & 7 & 33 & 24 & 87 \\
\hline Asia & 26 & 4 & 24 & 26 & 80 \\
\hline Africa & 11 & 1 & 5 & 11 & 28 \\
\hline North America & 9 & 1 & 6 & 9 & 25 \\
\hline South America & 15 & 2 & 3 & 1 & 21 \\
\hline Australia & 2 & 0 & 2 & 7 & 11 \\
\hline \multicolumn{6}{|c|}{ Memberships of the companies } \\
\hline Member of IATA & 47 & 9 & 39 & 57 & 152 \\
\hline In Top 100 & 4 & & 5 & 6 & 15 \\
\hline $\begin{array}{r}\text { Both Member of } \\
\text { IATA and in Top } 100\end{array}$ & 35 & 6 & 29 & 15 & 85 \\
\hline
\end{tabular}

$163(93.7 \%)$ companies declared their mission statements in English, 39 (22.4\%) in French 38 (21.8\%) in German, 39 (22.4\%) in Spanish, 32 (18.4\%) in Russian, 27 (15.5\%) in Italian, $24(13.8 \%)$ in Portuguese and $23(13.2 \%)$ in Chinese. As an addition, the 62 (35.6\%) airline companies in the "Others" category had one or more language options among the following for the mission statement: Japanese, Korean, Dutch, Turkish, Polish, Swedish, Danish, 
Norwegian, Arabic, Hungarian, Greek, Czech, Thai, Finnish, Romanian, Slovak, Bulgarian, Estonian, Hebrew, Slovenian, Catalan, Vietnamese, Croatian, Ukrainian, Serbian, Latvian, Persian, Lithuanian, Indonesian, Kazakh, Malay, Albanian, Macedonian, Armenian, Swahili and Afrikaans.

Table 2. The relationship between the numbers of language options for websites and mission statements of the airline companies

\begin{tabular}{|c|c|c|c|c|c|c|c|c|c|c|c|c|}
\hline \multirow{13}{*}{ 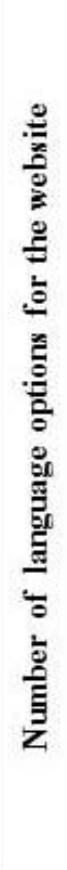 } & & \multicolumn{11}{|c|}{ Number of language options provided for the mission statement } \\
\hline & & 1 & 2 & 3 & 4 & 5 & 6 & 7 & 8 & 9 & $10+$ & Total \\
\hline & 1 & 18 & & & & & & & & & & 18 \\
\hline & 2 & 12 & 46 & & & & & & & & & 58 \\
\hline & 3 & 2. & 3 & 13 & & & & & & & & 18 \\
\hline & 4 & 2 & 2 & & 8 & & & & & & & 12 \\
\hline & 5 & & 6 & & & 4 & & & & & & 10 \\
\hline & 6 & 3 & 2 & 1 & & & 6 & & & & & 12 \\
\hline & 7 & 2 & 1 & & & 1 & & 3 & & & & 7 \\
\hline & 8 & 2 & 1 & & & & & 1 & 1 & & & 5 \\
\hline & 9 & & 2 & & & & & & 2 & 3 & & 7 \\
\hline & $10+$ & 8 & 8 & & & 2 & & & & & 9 & 27 \\
\hline & Total & 49 & 71 & 14 & 8 & 7 & 6 & 4 & 3 & 3 & 9 & 174 \\
\hline
\end{tabular}

Table 3 demonstrates the relationship between the place of the mission statement on the website and the number of language options provided for it. $33(32.7 \%)$ of the companies which placed the mission statement under "Our Mission" title or in the "Mission" link had no language options (statements were given in English), 39 (38.6\%) had two (generally the native language and English) and 6 (5.9\%) had three. Among the company websites which gave the mission statement implicitly, $16(21.9 \%)$ websites gave this information in one language, $32(43.8 \%)$ gave it in two languages and $8(11.0 \%)$ gave it in three languages.

While doing the research on the location of the mission statement on the websites, it has been seen that only euroAtlantic Airways had their mission statement located on the homepage of their website. The mission statement was on the first page of the websites of $49(28.2 \%)$ companies, on the second page of the websites of 68 (39.1\%) companies, on the third page of the websites of $42(24.1 \%)$ companies, on the fourth page of the websites of $11(6.3 \%)$ companies and on the fifth page of the websites of 2 companies (Corsair and LAN Airlines). See Table 4 to examine the relationship between the page number of the mission statement and the language options offered for the mission statement. 
Table 3. The relationship between the location of the mission statement on the website and the number of language options provided

\begin{tabular}{|c|c|c|c|c|}
\hline \multirow{2}{*}{$\begin{array}{l}\text { The number of } \\
\text { language options } \\
\text { for the mission } \\
\text { statement }\end{array}$} & \multicolumn{3}{|c|}{ The location of the mission statement on the website } & \multirow[b]{2}{*}{ Total } \\
\hline & $\begin{array}{l}\text { Under the title } \\
\text { "Our Mission" }\end{array}$ & $\begin{array}{l}\text { Under the link } \\
\text { "Mission", below } \\
\text { different titles }\end{array}$ & $\begin{array}{l}\text { Not specified as } \\
\text { the mission but } \\
\text { has the content }\end{array}$ & \\
\hline 1 & 28 & 5 & 16 & 49 \\
\hline 2 & 33 & 6 & 32 & 71 \\
\hline 3 & 6 & & 8 & 14 \\
\hline 4 & 4 & 2 & 2 & 8 \\
\hline 5 & 4 & & 3 & 7 \\
\hline 6 & 1 & & 5 & 6 \\
\hline 7 & 3 & & 1 & 4 \\
\hline 8 & 1 & 1 & 1 & 3 \\
\hline 9 & 1 & & 1 & 3 \\
\hline $10+$ & 4 & 1 & 4 & 9 \\
\hline Total & 86 & 15 & 73 & 174 \\
\hline
\end{tabular}

Table 4. The relationship between the page number of the mission statement on the website and the number of language options provided

\begin{tabular}{|c|c|c|c|c|c|c|c|c|}
\hline \multirow{2}{*}{$\begin{array}{l}\text { The number } \\
\text { of language } \\
\text { options for } \\
\text { the mission } \\
\text { statement }\end{array}$} & \multicolumn{7}{|c|}{ The page number of the mission statement } & \multirow[b]{2}{*}{ Total } \\
\hline & Home Page & lst Page & 2nd Page & 3rd Page & 4th Page & 5th Page & $\begin{array}{c}\text { Broken } \\
\text { Links }\end{array}$ & \\
\hline 1 & & 12 & 15 & 16 & 5 & & 1 & 49 \\
\hline 2 & & 19 & 31 & 14 & 5 & 2 & & 71 \\
\hline 3 & & 5 & 8 & & 1 & & & 14 \\
\hline 4 & & 1 & 4 & 3 & & & & 8 \\
\hline 5 & & 2 & 1 & 4 & & & & 7 \\
\hline 6 & & 2 & 4 & & & & & 6 \\
\hline 7 & & 1 & 2 & 1 & & & & 4 \\
\hline 8 & & 2 & & 1 & & & & 3 \\
\hline 9 & & 1 & & 2 & & & & 3 \\
\hline $10+$ & 1 & 4 & 3 & 1 & & & & 9 \\
\hline Total & 1 & 49 & 68 & 42 & 11 & 2 & 1 & 174 \\
\hline
\end{tabular}


As seen on Table 4, the company which placed its mission statement at the homepage also gave more than ten (eleven) language options. While $12(24.0 \%)$ of the companies which put their mission statement on the first page did not give language options, 19 (38.0\%) companies gave two and $18(36.7 \%)$ companies gave three or more language options. $15(22.0 \%)$ of the companies which put their mission statement on the second page did not give language options, $31(46.0 \%)$ companies gave two and $22(32.3 \%)$ companies gave three or more language options. $16(39.0 \%)$ of the companies which put their mission statement on the third page did not give language options, $11(27.0 \%)$ companies gave two and 14 companies gave three or more language options. It has also been seen that the companies which located their mission statements on the further pages gave three language languages at most (see Table 4).

The research on the categories in which the mission statements were placed under is as follows: The mission statements were under "About Company" for 114 (65.5\%) websites, under "Corporate Governance/Info" for 26 (14.9\%), under "Annual Report" for 12 (6.9\%), under "Policy/Strategy" for 7 (4.0\%), under "Code of Ethics/Conduct" for 5 (2.9\%), under "Investor/Customer Relations" for 5, under "Corporate/Company Culture" for 4 (2.3\%).

Table 5 displays the relationship between the location of the mission statement on the website, the category which the mission statement falls under and the number of language options provided for the mission statement. Under "Annual Report" (5 websites one, 7

Table 5. The relationship between the location of the mission statement on the website, the category which the mission statement falls under and the number of language options provided for the mission statement

\begin{tabular}{|c|c|c|c|c|c|c|c|c|c|c|c|c|}
\hline \multirow{2}{*}{$\begin{array}{l}\text { The location of the } \\
\text { mission statement on } \\
\text { the website }\end{array}$} & \multirow{2}{*}{$\begin{array}{l}\text { The category which the } \\
\text { mission statement falls under }\end{array}$} & \multicolumn{10}{|c|}{ Number of language options provided for the mission statement } & \multirow{2}{*}{ Total } \\
\hline & & 1 & 2 & 3 & 4 & 5 & 6 & 7 & 8 & 9 & $10+$ & \\
\hline \multirow{9}{*}{$\begin{array}{l}\text { Under the title "Our } \\
\text { Mission" }\end{array}$} & Main page & & & & & & & & & & 1 & 1 \\
\hline & About company & 16 & 16 & 4 & 4 & 4 & 1 & 3 & & & 3 & 51 \\
\hline & Corporate Governance/Info & 6 & 5 & & & & & & 1 & & & 12 \\
\hline & Policy/ Strategy & 1 & & 2 & & & & & & & & 5 \\
\hline & Code of Ethics/ Conduct & & 1 & 3 & & & & & & & & 4 \\
\hline & Corporate/ Company Culture & & 2 & & & & & & & & & 2 \\
\hline & Investor/ Customer Relations & 2 & 1 & & & & & & & & & 3 \\
\hline & Annual Report & 3 & 5 & & & & & & & & & 8 \\
\hline & Total & 28 & 30 & 9 & 4 & 4 & 1 & 3 & 1 & 2 & 4 & 86 \\
\hline \multirow{4}{*}{$\begin{array}{l}\text { Under the link } \\
\text { "Mission", below } \\
\text { different titles }\end{array}$} & About company & 1 & 6 & & 2 & & & & 1 & & 1 & 11 \\
\hline & Corporate/ Company Culture & 2 & & & & & & & & & & 2 \\
\hline & Annual Report & 2 & & & & & & & & & & 2 \\
\hline & Total & 5 & 6 & & 2 & & & & 1 & & 1 & 15 \\
\hline \multirow{7}{*}{$\begin{array}{l}\text { Not specified as the } \\
\text { mission but has the } \\
\text { content }\end{array}$} & About company & 11 & 23 & 6 & 2 & 2 & 4 & 1 & & & 3 & 52 \\
\hline & Corporate Governance/Info & 1 & 6 & 2 & 0 & 1 & 1 & & 1 & 1 & 1 & 14 \\
\hline & Policy/ Strategy & 2 & & & & & & & & & & 2 \\
\hline & Code of Ethics/Conduct & & 1 & & & & & & & & & 1 \\
\hline & Investor/ Customer Relations & 2 & & & & & & & & & & 2 \\
\hline & Annual Report & & 2 & & & & & & & & & 2 \\
\hline & Total & 16 & 32 & 8 & 2 & 3 & 5 & 1 & 1 & 1 & 4 & 73 \\
\hline
\end{tabular}


websites two languages), "Investor/Customer Relations" (4 websites one, 1 website two languages) and "Corporate/Company Culture" (2 websites one, 2 websites two languages) categories, the mission statements were given in one or two languages, while under "Policy/Strategy" and "Code of Ethics/Conduct" categories, the statements were given in three languages. The most amount of language options were given when the mission statement is under the category, "About Company". While 83 companies displayed their mission statements with three of fewer languages, 31 companies displayed it with four or more languages.

\section{Discussion and Conclusion}

The Internet can provide a cost-efficient gateway that would ensure global corporate communication for most organizations including small and medium-sized enterprises (Hamill, 1997). The result of our research which explores if the business operators use these gateways as a channel to inform their stakeholders about their missions was rather positive. Approximately $70 \%$ of the 252 airline companies included in the sampling published their mission statements on their official websites. However, only $40 \%$ percent of these companies gave their mission statements under the "Our Mission" title or link as a whole.

At the part of our research where the relationship between the continental locations of the companies and whether the companies announce their missions at their websites is examined, we have seen that all companies in South America apart from one included their mission statements to their websites. About a quarter of the African, North American, Asian and European companies, and more than half of the Australian airline companies did not give their mission statements on their websites. South American companies have the most percentage of giving the mission statement explicitly. The other continents follow in descending order as Africa, North America, Asia, Australia and Europe. It is possible to use some assumptions to explain this difference. The first possibility is the "follow-the-leader approach" regarding the organizational paradigm (Meyer \& Rowan, 1977). The companies from the same continent may be mimicking each other while designing websites. The second possibility is the belief that the mission statements are more of an internal communications tool rather than an external one (Leuthesser \& Kohli, 1997). The change in the existence and presentation of the mission statements on the company websites according to geographical locations may be attributed to changes in culture, management styles, governmental mechanisms and the power of the stakeholders (Culpan \& Kucukemiroglu, 1993; Knight \& Pretty, 2001). These factors may differentiate the European, Japanese and American companies' willingness to share their mission statements (Bartkus et al., 2002).

Most airline companies working globally have to prepare their websites in a language for the stakeholders to be able to understand. The result of this research indicates that most of the companies give English and the native language as the language options of the website. Most companies who give two language options for the website also provide their mission statement in those two languages. This situation which we attribute to English being accepted as the language of global communication is not acceptable. It is attention grabbing how companies publish their mission statements in so few languages although they have many 
stakeholders globally and multicultural. For example, DHL Air and DHL International which gives 33 language options and FedEx (Federal Express) which gives 20 language options for their websites, publish their mission statements only in English. Nevertheless, there are companies which have the necessary resources and are aware of the importance of announcing the mission statement, and these companies give more than 10 language options for both their websites and their mission statements. These companies are Air Berlin, Air China, Cathay Pacific Airways, Dragonair, Etihad Airways, euroAtlantic Airways, THY Turkish Airlines, TNT Airways and UPS Airlines - United Parcel Service.

The mission can be composed of various components. Considering airline companies, these components can be organizational goals, values, beliefs, philosophy, self-concept, desired public image, distinguishing qualities/unique identity, job description, vision, strategy (competition, price, corporate or general), responsibilities to various stakeholders (shareholders, employees/managers, customers, suppliers, public, state/regulatory authorities), offered products or services, geographical service area, technological highlights (flight-reservation or ticket sales), quality and innovation highlights, safety/security highlights, environmental impact). When a mission statement is published, it is essential to unite the ideas that the company wishes to convey as a whole so that the visitor would not have to go through different pages of the website in order to integrate the partial information regarding the mission. It is deemed positive that out of the 252 airline company websites, $32 \%$ placed the mission statement under "Our Mission" title, while 6\% gave a "Mission/Our Mission" link. Such navigational assistance provides the visitors a mental image that illustrates how the information is organized and what information are available (Van Berkel \& De Jong, 1999). While about half of the companies shared their mission statements as an integrated title, the other half spread this information throughout the website under various titles (Our Vision, Our Values, Our Strategy, Management Philosophy, or Responsibilities) and locations.

Homepage of a website is rather important. The most important information regarding the company is published on the homepage. Of 252 airline companies, only one of them shared its mission statement as a whole on the homepage. 19.4\% of these companies placed their mission statements on the first page, while $26.9 \%$ placed them on the second page, $16.6 \%$ on the third page, and $4.4 \%$ on the fourth page. In other words, the most frequent pages in which the mission statements are located on are the second, first, third, fourth pages and the homepage, in this particular order. In Bart's research (2001), which is similar to our research, the percentage of the websites publishing mission statements was 45. In this study, the most common locations for the mission statements are the second page $(19 \%)$, third page $(11 \%)$, fourth (or more) page (7\%), first page (4\%) and homepage (2\%). Both our studies and Bart's research showed that the companies often place their mission statement on the second or third page of the website.

Distinctive from the plain text reader, the Internet user chooses a page in which the information is separated into, and sees the pages one at a time. In the contrary, plain text is linear, and the reader does not need to choose. Because of this, reading a nonlinear text on a website may be more difficult than reading plain text. Visitors should be able to find the 
related information on the website with ease. When the visitors find the information they were looking for, they choose to see the next page. In the meantime, they need to continue to follow the current page (Van Berkel \& De Jong, 1999). In this case, it can be said that it is a small possibility for the visitors to see the mission statements on the company websites.

Mission, as a category, is important information for the company. It defines why a company was found, what its main purpose is, which philosophy, approach and values it uses while accomplishing this purpose and where it wants to see itself in the far future. That is the reason why it should be in the category, "About Company". Nearly half of the companies in our sampling (45\%) placed their mission statement under the category "About Company". Secondly, the mission is an organizational public statement. About $10 \%$ of the companies most probably considered this, and placed the mission under "Corporate Info/Governance", and 5\% placed it under "Annual Report". Mission statements are tools of politics and strategy. Assuming some companies interpreted the mission accordingly thus placed it under "Policy/Strategy" section. The mission statement is closely related to organizational culture and values. $2 \%$ of the companies placed the mission under "Ethics/Conduct" and $2 \%$ placed it under "Corporate/Company Culture", regarding this outlook. Among the companies in the sampling, only $3 \%$ placed the mission under a category which is directly related to stakeholders, which is "Investor/Customer Relations".

It is possible to deduce that a multilingual mission statement indicates a good understanding of the importance of the mission statement and the desire to reach global stakeholders. This deduction would lead to the prediction that the companies which give more than 10 language options for their mission statements would place the mission statement in the first two pages, under the mission link or "About Company" category. In our sampling, out of the companies who gave more than 10 language options for the mission statement, one placed it on the homepage, four placed it on the first page, three placed it on the second page and one placed it on the third page. Only five of these companies presented their mission statements as a whole. The mission statement was under "Our Mission" title in four companies' websites, under a separate link in another website, while four websites gave it without labeling it as the mission. Among these websites, one placed the mission statement on the home page, seven placed it under the category, "About Company", and one placed it under "Corporate Governance/Info". Air China, which is an Asian company, a member of IATA and also on the Top 100 list, gave the mission statement on the first page, under "About Company" category, under a separate link and as a whole.

In conclusion, the majority of the airline companies in our sampling use their websites to announce their mission statements, which is found positive. However, we believe that the websites are not being used to full effect in conveying the mission statements to the stakeholders. We should emphasize again that, to be effective, the websites and mission statements should be prepared in multiple languages, the mission statements should be placed under a separate link or title, should be placed on the homepage or on the first page, under the categories "About Company" and "About Us". 


\section{Limitations and future research}

This research is done on the websites of airline companies. Websites are generally dynamic due to constant updates. Because of this, the findings of this research should be evaluated regarding the date of the research. The websites in the sampling were examined between February 23rd and April 28th, 2011, and the research has been updated and revised between July 26th and August 24th, 2011. When doing a research on many companies, in spite of exceptional care, it is not simple to assure absolute standardization. For example, we counted the number or "clicks" to reach the mission statement from homepage. We assumed the title the mission statement was written under as the category. Generally, "Our Mission" link showed up when "About Company" or "About Us" links were clicked. In this case, we assumed the category as "About Company". Some gave the statement under "Annual Report", which is under "Investor Relations". In this case, we assumed the category as "Annual Report". During our research, we chose the category closest to the mission statement as the category.

In this research, the efficiency of the announcement of the mission statement is measured by the ease of locating and reaching it on the website. We believe that the information offered in this study is of importance to airline company executives and web designers. As a continuation of this study, we are analyzing the contents of the mission statements. By this approach, we will clarify if the airline companies announce their mission statements efficiently on their websites, and what elements do they include as content.

We believe that it is important to get consults from the stakeholders regarding the location and content of the mission statement on the website. While there are some studies regarding industrial and local companies, there are none about stakeholders of global airline companies. Furthermore, the alteration in a stakeholder's perception of the company after reading the mission statement, its direction and form and whether it affects buying behavior are among the topics that should be further researched.

\section{References}

Bart, C.K. (2001). Exploring the application of mission statements on the world wide web. Internet Research: Electronic Networking Applications and Policy, 11, 360-368. http://dx.doi.org/10.1108/10662240110402812

Bart, C.K. (1999). Mission statements content and hospital performance in the Canadian no-for-profit health care sector. Health Care Management Review, 24, 18-29.

Bart, C.K. \& Baetz, M.C. (1998). The relationship between mission statements and firm performance: an exploratory study. The Journal of Management Studies, 35, 823-853. http://dx.doi.org/10.1111/1467-6486.00121

Bart, C.K. (1997). Sex, lies, and mission statements. Business Horizons, 40, 9-18.

Bart, C.K. (1996). The impact of mission on firm innovativeness. International Journal of Technology Management, 11, 479-93. 
Bartkus, B.R. \& Glassman, M. (2008). Do firms practice what they preach? The relationship between mission statements and stakeholder management. Journal of Business Ethics, 83, 207-216. http://dx.doi.org/10.1007/s10551-007-9612-0

Bartkus, B., Glassman, M. \& Mcafee, B. (2002). Do large European, US and Japanese firms use their web sites to communicate their mission? European Management Journal, 20, 423-429.

Benckendorff, P. (2006). An exploratory analysis of traveler preferences for airline website content. Information Technology \& Tourism, 8, 149-159.

Benligiray, S., Geylan, A. \& Duman, E. (2009). Web sitelerinde vizyon ve misyonlarını açıklayan Türk işletmeleri ve ilişkili faktörlerin analizi. International Public Relations Symposium, (15-17 April Lefkoşa-KKTC), Proceedings, Antalya: Kros Ofset, 163-176.

Bennett, R. (1997). Export marketing and the internet. International Marketing Review, 14, 324-344. http://dx.doi.org/10.1108/02651339710184307

Breitenbach, C., \& Van Doren, D. (1998). Value added marketing in the digital domain: Enhancing the utility of the internet. Journal of Consumer Marketing, 15, 558-75. http://dx.doi.org/10.1108/07363769810241436

Campbell, A. (1989). Does your organization need a mission? Leadership and Organization Development, 10, 3-9. http://dx.doi.org/10.1108/EUM0000000001134

Campbell, A. (1993). The power of mission: Aligning strategy and culture. Planning Review, $20,10-12$.

Campbell, A. (1997). Mission statements. Long Range Planning, 30, 931-932. http://dx.doi.org/10.1016/S0024-6301(97)00084-8

Campbell, A., \& Tawadey, K. (1992). Mission business philosophy. Oxford: Butterworth-Heinnnman.

Campbell, A., \& Yeung, S. (1991). Creating a sense of mission. Long Range Planning, 24, 10-20. http://dx.doi.org/10.1016/0024-6301(91)90002-6

Chaffey, D., Mayer, R., Johnston, K., \& Ellis-Chadwick, F. (2003). Internet Marketing. Second ed. New York: Prentice-Hall, Englewood Cliffs.

Chakraborty, G., Srivastava, P. \& Warren, D. L. (2005). Understanding corporate B2B web sites' effectiveness from North American and European perspective. Industrial Marketing Management, 34, 420-429. http://dx.doi.org/10.1016/j.indmannan.2004.09.008

Culpan, R., \& Kucukemiroglu, O. (1993). A comparison of U.S. and Japanese management styles and unit. Management International Review, 33, 27-42.

Doganis, R. (2005). Flying Off Course. London: Routledge.

Drucker, P. F. (1973). Management: Tasks, responsibilities, practices. New York: Harper\& Row. 
Fisher, C. D., \& Gitelson, R. (1983). A meta-analysis of the correlates of role conflict and to employees. Journal of Applied Psychology, 68, 320-333.

General Accounting Office. (2003). Airline ticketing: Impact of changes in the airline ticket distribution industry. US GAO Report to Congressional Requesters.

Gilbert, D.C., Powell-Perry, J., \& Widijoso, S. (1999). Approaches by hotels to the use of the internet as a relationship marketing tool. Journal of Marketing Practice: Applied Marketing Science, 5, 21-38. http://dx.doi.org/10.1108/EUM0000000004549

Greengarten-Jackson, J., Yau, S.C., Gitlow, H., \& Scandura, T.T. (1996). Mission statements in service and industrial corporations. International Journal of Quality Science, 1, 48-61. http://dx.doi.org/10.1108/13598539610117984

Hamill, J. H. (1997). The Internet and international marketing. International Marketing Review, 14, 300-323. http://dx.doi.org/10.1108/02651339710184280

Harker, M. J. (1999). Relationship marketing defined? An examination of current relationship marketing definitions. Marketing Intelligence and Planning, 17, 13-20. http://dx.doi.org/10.1108/02634509910253768

Ho, J. (1997). Evaluating the World Wide Web: A global study of commercial sites. Journal of Computer Mediated Communication, 3, 1-30.

Ireland, R., \& Hitt, M. (1992). Mission statements: Importance, challenge and recommendations for development. Business Horizons, 35, 34-43. http://dx.doi.org/10.1016/0007-6813(92)90067

Jeong M., Oh, H., \& Gregoire, M. (2003). Conceptualizing web site quality and its consequences in the lodging industry. International Journal of Hospitality Management, 22, 161-75. http://dx.doi.org/10.1016/S0278-4319(03)00016-1

Klemm, M., Sanderson, S., \& Luffman, G. (1991). Mission statements: Selling corporate values to employees. Long Range Planning, 24, 73-8. http://dx.doi.org/10.1016/0024-6301(91)90187-S

Knight, R., \& Pretty, D. (2001). Mastering investment: Seeking value from changes in Europe. Financial Times, June 25.

Kuyucak, F. (2007). Havaalanlarında değer odaklı yönetim yönelimli bilgi sistemlerinin kullanılması ve Atatürk Havalimanı terminal işletmeciliği uygulaması (Unpublished doctoral dissertation). Anadolu University, Eskisehir.

Leuthesser, L., \& Kohli, C. (1997). Corporate identity: The role of mission statements. Business Horizons, 40, 59-67. http://dx.doi.org/10.1016/S0007-6813(97)90053-7

Lubbe, B. (2007). The effect of internet apprehension and website satisfaction on air travellers' adoption of an airline's website. Journal of Air Transport Management, 13, 75-80. http://dx.doi.org/10.1016/j.jairtraman.2006.10.007 
Meyer, J. W., \& Rowan, B. (1977). Institutionalized organizations: Formal structure as myth and ceremony. American Journal of Sociology, 83, 340-363

Murphy, J., Forrest, E., Wotring, C., \& Brymer, R. (1996). Hotel management and marketing on the internet: An analysis of sites and features. Hotel and Restaurant Administration Quarterly, 37, 70-82. http://dx.doi.org/10.1016/0010-8804(96)86817-0

Palmer, J. (2002). Designing for web site usability. Computer, 35, 102-103. http://dx.doi.org/10.1109/MC.2002.1016906

Pearce, J. A. (1982). The company mission as a strategic tool. Sloan Management Review, 23, $15-24$.

Pearce, J. A. II \& Roth, K. (1988). Multi nationalization of the mission statement. SAM Advanced Management Journal, 39-44.

Peppers, D., \& Rogers, M. (2001). One to one B2B. New York: NY7 Currency Books.

Perdue, R. (2001). Internet site evaluations: The influence of behavioral experience, existing images, and selected website characteristics. Journal of Travel \& Tourism Marketing, 11, 21-38. http://dx.doi.org/10.1300/J073v11n02_02

Rachman, Z., \& Richins, H. (1997). The status of New Zealand Tour Operator web sites. Journal of Tourism Studies, 8, 62-77.

Rigby, D. K. (1994). Managing the management tools. Planning Review, 22, 20-4.

Rigby, R. (1998). Mission statements. Management Today, March, 56-59.

Robbins, S. S., \& Stylianou, A. C. (2001-2002). A study of cultural differences in global corporate web sites. Journal of Computer Information Systems, 42, 3-10.

Stolkey, R. C. (2004). Getting everybody on the same page. Handbook of Business Strategy, 5, 171-172.

Van B. A., \& De Jong, M. (1999). Coherence phenomena in hyper textual environments. In E. M. Jakobs (Ed.), Textproduktion: HyperText (29-40). Frankfurt: Lang.

Want, J. H. (1986). Corporate mission. Management Review. August, 46-50.

Yelkur, R., \& Dacosta, M. M.,N. (2001). Differential pricing and segmentation on the internet: the case of hotels. Management Decision. 39, 252-262. http://dx.doi.org/10.1108/00251740110391411

http://www.iata.org/membership/Pages/airline_members_list.aspx?All=true (R: August, 20, 2011)

Airline Business; Aug 2010; 26, 8; ABI/INFORM Trade \& Industry pg. 56 (R: August, 20, 2011)

\section{Glossary}




\section{Macrothink}

B2B : Business-to-Business

DHL : Adrian Dalsey, Larry Hillblom, Robert Lynn

FedEx : Federal Express

GAO : General Accounting Office

IATA : International Air Transport Association

TNT : Thomas Nationwide Transport

THY : Turkish Airlines

UPS : United Parcel Service

\section{Copyright Disclaimer}

Copyright reserved by the author(s).

This article is an open-access article distributed under the terms and conditions of the Creative Commons Attribution license (http://creativecommons.org/licenses/by/3.0/). 


\section{Appendix-A}

Adria Airways

http://issuu.com/akersnic/ docs/adria airways annua 1 report 2009 en?mode $=$ embed\&layout $=$ http $\% 3 \mathrm{~A}$ $\% 2 \mathrm{~F} \% 2 \mathrm{Fskin}$.issuu.com

Aegean Airlines

http://en.aegeanair.com/all -about-us/corporateresponsibility/unglobal-

compact/

\section{Aer Lingus}

http://www.aerlingus.com/ aboutus/aerlingusmedia/co mpanyprofile/

Aero República S.A

Copa Airlines (Yeni ismi

Copa Airlines Colombia)

http://investor.shareholder

.com/copa/index.cfm

Aeroflot Russian

Airlines

http://www.aeroflot.ru/cm s/en/about/strategy

Aerolineas Argentinas

S.A.

http://www.aerolineas.co

m.ar/arg/main.asp?idSitio

$=$ EU\&idPagina $=10 \&$ idId

oma $=$ en

Aeromexico

http://www.aeromexico.co $\mathrm{m} / \mathrm{us}$ /ExperienceAeromexi

co/AeromexicoCorporate/

Report_on_Actions_of_so cial Responsability.pdf

\section{Air Astana}

http://www.airastana.com/

int/tr/Mission-Goals-and-

Values.aspx

Air Austral

http://www.air-

austral.com/en/about-air-

austral/quality-and-

safety.html

Air Berlin

http://www.airberlin.com/

site/company/profile/index

.php? LANG=eng\&cat=str

ategie

http://ir.airberlin.com/inde

x.php?id $=\& \mathrm{~L}=2$

Air Canada

http://www.aircanada.com /en/about/index.html

Air China

http://www.airchina.com.c n/www/en/html/index/abo ut us/company profile/

Air Europa

http://www.aireuropa.com /uk/en/informacion/corp_a ir europa.htm

Air France http://corporate.airfrance.c om/en/the-airline/at-aglance

Air Macau

http://en.airmacau.com.mo /about/company.asp\#3

Air Madagascar

http://www.airmadagascar com/en/our-company/airmadagascar-

commitments.html

Air Malawi

http://www.airmalawi.co m/AboutUs/tabid/97/Defa ult.aspx

\section{Air Mauritius}

http://www.airmauritius.c om/investors/MKAnnualR eport07 08.pdf

Air Moldova

http://www.airmoldova.m

d/about-company-en/

Air Namibia

http://www.airnamibia.co m.na/node/8

Air New Zealand

http://www.airnewzealand co.nz/corporate-profile

Air Nostrum

http://www.airnostrum.es/ ficheros/245 2 ENVIRO NMENTAL\%20POLICY. pdf

Air Seychelles

http://www.airseychelles.c om/en/about us/vision mi ssion.php

Air Tahiti

http://www.airtahiti.aero/a rticles.php?id=61

Air Transat

http://resp.transat.com/en/ message-frommanagement.html

Air Zimbabwe

http://www.airzimbabwe.a ero/air-zimbabwe-

holdings.htm

\section{AirAsia}

http://www.airasia.com/m $\mathrm{y} / \mathrm{en} /$ corporate/corporatep ofile.page?

AirLink

http://www.flyairlink.com about us/mission statem ent.php

AirTran Airways

http://www.airtranairways. com/about-

us/corporate info.aspx?na $\mathrm{v} \mathrm{id=107}$

Alaska Airlines

http://www.alaskaair.com/ content/about-us.aspx
Alitalia

http://corporate.alitalia.it/e n/Images/Alitalia Ethics t cm7-38337.pdf

American Airlines

http://www.americanairlin es.ie/i18n/aboutUs/corpor ateResponsibility/main.jsp

ANA-All Nippon

Airways

http://www.ana.co.jp/wws japan/e/wws common/ab

out ana

Armavia

http://www.armavia.am/in dex/view/id/308/lang/en

Asiana

http://us.flyasiana.com/G obal/US/en/homepage?fid $=$ ABOUT11120

Atlas Air

http://www.atlasair.com/h oldings/2Q11EarningsCall pdf

Atlasjet Airlines

http://cmss.atlasjet.com/tr/ kurumsal/hakkimizda

Austral Lineas Aereas

http://www.austral.com.ar/ arg/main.asp?idSitio=AR \&idPagina $=10$ \&idIdioma

=es

Austrian Airlines

http://www.austrianairline s.ag/AustrianAirlinesGrou p/Profil/MissionStatement aspx?sc lang=en

Avianca

http://www.avianca.com AcercaAvianca/Nuestra+h istoria/en/Mision-Vision-

Valores.htm

B\&H Airlines

http://www.bhairlines.ba/t urkish/o nama/misija.php

Belavia - Belarusian

Airlines

http://en.belavia.by/compa ny/

Blue Panorama Airlines

http://www.blue-

panorama.com/eng/index a.htm

Blue

http://www.bluel.com/en Other/About-

us/Company -

information/Businessconcept

bmi-British Midland

Airways

http://www.flybmi.com/b mi/en-gb/about-us/aboutbmi/about-bmi.aspx
British Airways

http://www.britishairways com/travel/csr-corporateresponsibility/public/en tr ?link=main nav

Brussels Airlines

http://company,brusselsair ines.com/en be/corp/ourcompany/our-brand.aspx Bulgaria Air

http://www.air.bg/en/abou t-us/

Caribbean Airlines

http://www.caribbeanairlines.com/index.php/co ntact-us/about-us

Carpatair

http://www.carpatair.com/ About us/Company profi le/Mission/EN/

Cathay Pacific Airways

http://www.cathaypacific. com/cpa/en_INTL/aboutus cxbackground/missionstat ement

China Airlines

http://www.chinaairlines.com/ch/about/98a p.pdf

Cimber Sterling A/S

http://www.cimber.com/a boutcimber/cimbersterling brief/

Copa Airlines

http://investor.shareholder .com/copa/overview.cfm\# strategy

Corsair

http://www.tuigroup.com/en/ir/TUI_Gro up/Business model

Croatia Airlines

http://www.croatiaairlines. com/en/nbspnbspnbspnbs paboutusnbspnbspnbsp/m anagement/tabid/193/Defa ult.aspx

Cubana

http://www.cubana.cu/gui $\mathrm{de} /$ ?article $=$ co-mision

Czech Airlines

http://www.csa.cz/en/porta l/company/about_us.htm DHL Air

http://www.dhlbrandworld.com/en/ourmission.html

DHL International

http://www.dhlbrandworld.com/en/ourmission.html

Donavia JSC 
http://www.aeroflotdon.ru/company.aspx?no= 1031 \&language $=$ en

Dragonair

http://www.dragonair.com da/en_INTL/aboutus/abo utdragonair/introdragonair Dubrovnik Airline

http://www.dubrovnikairli ne.com/DAWeb/en/vizija. html

easyJet

http://corporate.easyjet.co m/about-

easyjet.aspx?sc lang=en\#

Egyptair

http://www.egyptair.com/ English/Pages/MissionVis ion.aspx

EL AL

http://www.elal.co.il/ELA L/English/AboutEIAl/His ory.htm

Emirates

http://www.theemiratesgro up.com/english/our-

vision-values/our-vision-

values.aspx

Estonian Air

http://www.estonianair.ee/estonian_air_strateg

Ethiopian Airlines

http://www.ethiopianairlin es.com/en/corporate/visio nmission.aspx

Etihad Airways

http://www.etihadairways. com/sites/etihad/ae/en/abo utetihad/etihadstory/pages/ etihadvision.asp $\mathrm{x}$

euroAtlantic Airways

http://www.euroatlantic.pt html/en homepage.asp

Eurowings

http://www.eurowings.de

\section{EVA Air}

http://www.evaair.com/ht $\mathrm{ml} / \mathrm{b} 2 \mathrm{c} /$ english/eva/Corpo ate profile/Corporate mis sion/

FedEx-Federal Express

http://about.fedex.designc dt.com/our company/com pany information $/ \mathrm{mission}$ statement

Finnair

http://www.finnairgroup.c om/group/group 2.html

GOL Transportes

Aereos

http://www.voegol.com.br int/Gol/AboutUs/Paginas

Proposal.aspx

Hainan Airlines http://global.hnair.com/en classlist.php?bo=bottom/A bout Us/introduction.html Hawaiian Airlines

http://global.hnair.com/en/ classlist.php?bo=bottom $/ \mathrm{A}$ bout Us/introduction.htm Iberia

http://grupo.iberia.es/porta 1/site/grupoiberia/menuite m.5a459edec4a85bc 94857 $71 \mathrm{fbf} 34 \mathrm{e} 51 \mathrm{ca}$

\section{Icelandair}

http://www.icelandairgrou p.com/about-us/

Iran Air

http://www.iranair.com/sit e/305/default.aspx

\section{JAL-Japan Airlines}

http://www.jal.com/en/ir/f inance/annual/

Jat Airways

http://www.jat.com/active/ en/home/main menu/abou t us/company profile.htm I

Jazeera Airways

http://www.jazeeraairways com/Careers.aspx?Lang= En

Jet Airways

http://www.jetairways.co $\mathrm{m} / \mathrm{EN} / \mathrm{IN} / \mathrm{AboutUs} /$ OurM ssionStatement.aspx

\section{JetBlue}

http://library.corporate-

ir.net/library/13/131/1310

45/items/211505/05ar.pdf

JetLite

http://www.jetlite.com/in/

aboutjetlite.aspx

JSC Nordavia

http://www.nordavia.ru/en g/about/

Kenya Airways

http://www.kenya-

airways.com/home/about

kenya airways/history/mi

ssion and vision/default.a $\underline{s p x}$

Kingfisher Airlines

http://www.flykingfisher.c om/about-us/visionvalues.aspx

Kish Air

http://kishairline.com/en/k ishair-history

KLM

http://www.klm.com/corp orate/en/about-

$\mathrm{klm} /$ profile/index.html

Korean Air

http://www.koreanair.com L

Kuwait Airlines http://www.kuwaitairways.com/Default.aspx ?pageld $=22 \& \mathrm{mid}=15$

LACSA

http://www.taca.com/pdf/c ode of ethics eng.pdf

LAM

http://www.lam.co.mz/en/ Company/Company-

History/Company-Mission

LAN Airlines

http://www.marketinglan.

com/memoria-

lan/html/externos/portable

investor relations/memor

ia anual $/ 2010 / \mathrm{en} / \mathrm{memoria}$

htm

Lan Argentina

http://www.lan.com/files/a

bout us/lanchile/memoria

2009.pdf

Lan Cargo

http://en.lancargo.com/co

mpany/our-company

LanEcuador

http://www.lan.com/files/a

bout us/lanchile/memoria

2009.pdf

LanPeru

http://www.lan.com/files/a bout_us/lanchile/memoria 2009.pdf

Lauda Air

http://www.laudaair.com/s ite/index.php?id=4\&L=1

LOT Polish Airlines

http://www.lot.com/web/

ot/mission-and-vision

Lufthansa

http://konzern.lufthansa.co

$\mathrm{m} / \mathrm{en} / \mathrm{company} . \mathrm{html}$

LufthansaCargo

http://konzern.lufthansa.co

$\mathrm{m} / \mathrm{en} /$ company.html

LufthansCityLine

http://konzern.lufthansa.co $\mathrm{m} / \mathrm{en} /$ company.html

Luxair

http://www.luxairgroup.lu cms/luxair.php?page\&p= EN,9147,176,.1..

Malaysia Airline

http://www.malaysiaairlin es.com.my/my/en/corporat e-info/our-story.html

MALEV

http://www.malev.com/co mpanyinformation

Malmö

http://www.malmoaviatio n.se/o.o.i.s/8013

MAS Air

http://masair.com/english/ nosotros.html

MEA
http://www.mea.com.lb/E nglish/Corporate/Pages/Hi storyAndNetwork.aspx

Meridiana Fly

http://www.meridiana.it/c ms/deploy/1//GGJ Docu menti/IT/Codiceetico/Meri dianaGroupEthicalCode.p df

Monarch Airlines

http://www.monarch.co.uk about-

us/corporate/monarch-

group

Nouvelair

http://www.nouvelair.com

/en/content/about-

nouvelair

Olimpic Airlines

http://www.olympicair.co $\mathrm{m} /$ Default.aspx?a id $=564$

Oman Air

http://www.omanair.com wy/about-us/corporate-

information/mission-

statement

Onur Air

http://www.onurair.com.tr /vizyon_ve_misyon.aspx

PAL-Philippine Airlines

http://www.philippineairli nes.com/about_pal/about

pal.jsp

Pegasus

http://www.flypgs.com/en

about-pegasus/pegasus-

history.aspx

PGA-Potugalia Airlines

http://www.flytap.com/W orld/en/Company/TAP/

International Airlines

http://www.piac.com.pk/P

IA About/profiles/2009/A nnualReport2009 310320

10.pdf

Precision Air

http://www.precisionairtz. com/index.php/corporate/ mission-a-vision

Qantas

http://www.qantas.com.au infodetail/about/investors

2010AnnualReport.pdf

Qatar Airways

http://www.qatarairways.c om/global/en/careers.html Rossiya Airlines

http://www.rossiyaairlines.com/en/about/abo utus/history/

Royal Jordanian

http://www.ri.com/en/tabi d/120/Default.aspx

Ryanair 
http://www.ryanair.com/e n/about

SAA - South African

Airways

http://www.flysaa.com/Jo urneys/about_US.action

SATA Air Açores

http://www.sata.pt/en/sata/

grupo-sata-en

Saudi Arabian Airlines

http://www.saudiairlines.c om/portal/site/saudiairline

s/menuitem.d9a467d070ca $\underline{6 \mathrm{c} 65173 \mathrm{ff} 63 \mathrm{dc} 8 \mathrm{f0} 034 \mathrm{a} 0 / ? \mathrm{v}}$ gnextoid $=3 \mathrm{e} 643 \mathrm{bf} 6 \mathrm{~b} 92 \mathrm{c} 4$ $110 \mathrm{VgnVCM} 10000015 \mathrm{e} 2$ 5558RCRD

Shandong Airlines

http://www.shandongair.c om/web/shair en/corporat e

Shanghai Airlines

http://wwl.shanghaiair.com/PublicInfoen/saboutus.aspx?page $=a b$ outus/sali.asp

Shenzhen Airlines

http://www.shenzhenair.co $\underline{\mathrm{m} / \text { module/about/about_1.j }}$ sp

SIA Cargo

http://www.singaporeair.c om/en_UK/about-us/

SIA-Singapore Airlines

http://www.singaporeair.c om/en_UK/about-us/

Siberia Airlines

http://www.s7.ru/en/about us/corporate info/index. $\underline{\mathrm{html}}$

\section{Silkair}

http://www.silkair.com/m be/en UK/content/corpora te/index.jsp?JSESSIONID $=\mathrm{n} 8 \mathrm{yFNJQZBxLLN17Ly4}$ npMMpn72QcF5vdWKx2 pp06mlvs9N1mQnhp!161 0961355!-181437831

\section{Sky Airlines}

https://www.skyairlines,ne t/ic hatlar/hakkimizda.sky

South African Express

\section{Airways}

http://www.flyexpress.aer

o/images/sax-annual-

report-2009-2010.pdf

Southwest Airlines

http://www.southwest.co

$\mathrm{m} / \mathrm{html} /$ about-

southwest/index.html?int=

GFOOTER-ABOUT-

MISSION

Srilankan

http://www.srilankan.aero/ about-srilanka/srilankantoday/vision-mission.html
Sunexpress

http://www.sunexpress.co

$\mathrm{m} / \mathrm{xq} / \mathrm{en} / \mathrm{about}$

sunexpress/company-

profile.jsp

Surinam Airways

http://www.slm.firm.sr/en/ content $/ 2 /$ about-

us $/ 2 /$ mission

Swiss

http://www.swiss.com/we b/EN/about_swiss/compan $\mathrm{y} / \mathrm{Pages} /$ facts figures.aspx Syrianair

http://www.syriaair.com/ AboutSAA/Objectives/tab id/55/Default.aspx

TAAG-Angola Airlines

http://www.taag.com/en/vi sion.aspx

TACA International

http://www.taca.com/pdf/c ode of ethics eng.pdf

TACA Peru

http://www.taca.com/pdf/c ode of ethics eng.pdf

TAM

http://tam.riweb.com.br/de fault.aspx

TAM Linhas Aereas

http://tam.riweb.com.br/de fault.aspx

TAME

http://www.tame.com.ec/i ndex.php?option $=$ com_co ntent\&view $=$ article\&id $=1$ 3 \&Itemid $=21$ \&lang $=$ en

TAP Portugal

http://www.flytap.com/W orld/en/Company/TAP

TAROM

http://www.tarom.ro/en/ta rom-company/goals

Thai Airways

http://thai.listedcompany.c om/misc/ar/en/ar2010.pdf

Thomson Airways

http://www.tuitravelplc.co $\mathrm{m} /$ tui/pages/aboutus/strate

\section{THY-Turkish Airlines}

http://www.turkishairlines .com/en-

INT/corporate/about_us/m

ission.aspx

Tianjin Airlines

http://www.tianjinair.com/frontend/informati on/newInfo/main one 27. isp

TNT Airways

http://www.tnt.com/expres s/en ip/site/home/about u s/mission_and_vision.html

Transaero Airline http://transaero.ru/en/com pany/safetyquality

TUIfly GmbH

http://www.tuifly.com/en/ unternehmen tuifly/index. html

Ukraine International

Airlines

http://www.ukraine-

international.com/eng/com

pany/ukraine-

international-

airlines/uia/Company-

Profile.html

UPS Airlines-United

Parcel Service

http://www.ups.com/conte $\mathrm{nt} / \mathrm{tr} / \mathrm{en} / \mathrm{about} / \mathrm{index} . \mathrm{html}$ ?

WT.svl=Footer-

UT air

http://www.utair.ru/en/abo ut/mission/

V Australia

http://www.vaustralia.com

au/about-us/media-

releases/view-media-

releases/P 007537.htm

Vietnam Airlines

http://www.vietnamairline s.com/wps/portal/en/site/a bout us/corporate respon sibilities/!ut/p/c5/IY9LDo JAEETP4gmmaGAGlsNv AAGNkYhsDAtiMAIujO cXXAmKxu7ly0tVsZL13 1b3-ITd6q6tLqxgJT4SoaGSIAVNzko80yl0j0 NAe 5 oVbZPugLME6i WgjJEN2jo9VaSJJNZdiy a2StMAJHJLbPxMA8y ifcET_s3bB1trsKza_8uW 3gmDmJifh34i r8 Crimy a5PnBerobMjFA8zyZbY! /dl3/d3/L3dDb0EvUU5R TGtBISEvWUZSdndBIS EvN19DR0FINDdMMDB PNjU2MDJGRDILRzNE MUcwMA!!

Virgin Atlantic Airways http://www.virginatlantic.com/en/gb/allabou tus/missionstatement/inde $\mathrm{x.jsp}$

Vladivostok Air JSC

http://www.vladivostokavi a.ru/en/about/fact sheet/

Volaris Airlines

(Concesionara Vuela

Comania de Aviación,

SA de CV)

http://contenido.volaris.co m.mx/ContenidoWEB201 0/docs/Conocenos/enUS/nuestra historia en.pd f

Volga-Dnepr Airlines

JSC http://www.volga-

dnepr.com/eng/group/com panies/profile/

VRG Linhas Aéreas S.A

http://www.voegol.com.br int/Gol/AboutUs/Paginas Proposal.aspx

WestJet Airlines

http://www.westjet.com/g uest/en/about/index.shtml White Airways S.A.

http://www.flywhite.eu/in

dex.php?option $=$ com cont ent\&task=view\&id=13\&It emid $=104 \&$ lang $=$ en

Wideroe

http://www.wideroe.no/str eam file.asp?iEntityId $=12$ $\underline{02}$ 